Федотова Ю. В., к.е.н., доцент

Харківський національний університет

міського господарства

імені О. М. Бекетова

м. Харків, Україна

DOI: https://doi.org/10.30525/978-9934-26-080-3-22

\title{
ОЦІНКА ЕКОНОМІЧНОЇ ЕФЕКТИВНОСТІ ЕКСПОРТНО-ІМПОРТНОЇ ДІЯЛЬНОСТІ ПІДПРИЕМСТВА
}

Актуальність зовнішньоекономічної діяльності підприємств сьогодні не викликає сумнівів. У таких умовах важливим $є$ аналіз особливостей процесу зовнішньоторговельних операцій і факторів, які впливають на їх кінцевий результат. На стадії планування виходу підприємства на зовнішній ринок рівень ефективності тісно пов'язаний із ступенем зацікавленості підприємства у виході на конкретні ринки товарів i/або послуг. На стадії безпосереднього здійснення зовнішньоекономічної діяльності показники піi ефективності дозволяють виявити негативні тенденції, що є індикатором для прийняття певних управлінських рішень стосовно необхідності усунення негативних чинників, у випадку неможливості їх нівелювання - повної відмови від такої діяльності.

Звертаючись до термінологічного апарату, слід зазначити, що «зовнішньоекономічні операції» - комплекс дій контрагентів різних країн стосовно реалізації торговельного обміну. Економічна наука розрізняє поняття «ефект» та «ефективність», під першим розуміють результат заходу, а під другим терміном співвідношення результатів і витрат, які його спровокували [1, с. 112].

Для аналізу зовнішньоекономічної діяльності підприємства використовується сукупність аналітичних показників. 
Порядок оцінки ефективності зовнішньоекономічної діяльності підприємства

\begin{tabular}{|c|c|c|}
\hline Назва & Формула & Позначення \\
\hline 1 & 2 & 3 \\
\hline $\begin{array}{c}\text { Питома вага } \\
\text { сум контрактів, } \\
\text { прострочених } \\
\text { у звітному періоді }\end{array}$ & Іп. к. $=\frac{\text { Кп }}{\text { Кв }_{\mathrm{B}}} \times 100 \%$ & $\begin{array}{c}\mathrm{K}_{\text {п }}-\text { сума контрактів, } \\
\text { прострочених протягом } \\
\text { року; } \\
\text { К }_{\text {в }} \text { сума контрактів, } \\
\text { які підлягають } \\
\text { виконанню у звітному } \\
\text { періоді }\end{array}$ \\
\hline $\begin{array}{l}\text { Коефіцієнт виконання } \\
\text { зобов’язань за } \\
\text { вартістю }\end{array}$ & $\mathrm{K}^{\text {варт }}=\frac{\sum_{i=1}^{n} Q_{\mathrm{i} \phi} \times \mathrm{P}_{\mathrm{i} \phi}}{\sum_{i=1}^{n} Q_{\mathrm{i} n} \times \mathrm{P}_{\mathrm{i} n}}$ & $\begin{array}{c}\mathrm{P}_{\text {іф }} \mathrm{i} \mathrm{Q}_{\text {іф }} \text { фактичні } \\
\text { ціни та кількість } \\
\text { товару i; } \\
\mathrm{P}_{\text {in }} \text { i } \mathrm{Q}_{\text {in }}-\text { планові ціни } \\
\text { та кількість товару i; } \\
\text { n - кількість товарів }\end{array}$ \\
\hline $\begin{array}{c}\text { Коефіцієнт виконання } \\
\text { зобов’язань } \\
\text { з експорту товарів } \\
\text { за фізичним обсягом }\end{array}$ & $\mathrm{K}^{\text {фіз.об. }}=\frac{\sum_{i=1}^{n} Q_{\mathrm{i \phi}} \times \mathrm{P}_{\text {iп }}}{\sum_{i=1}^{n} Q_{\mathrm{i \phi}} \times \mathrm{P}_{\text {іп }}}$ & $\begin{array}{c}\mathrm{Q}_{\text {iф }}-\text { фактична } \\
\text { кількість; } \\
\mathrm{P}_{\text {in }} \text { i } \mathrm{Q}_{\text {in }}-\text { планові ціни } \\
\text { та кількість товару і; } \\
\mathrm{n}-\text { кількість товарів }\end{array}$ \\
\hline $\begin{array}{c}\text { Коефіцієнт виконання } \\
\text { зобов’язань } \\
3 \text { експорту товарів } \\
\text { з ціною }\end{array}$ & $\mathrm{K}^{\text {ціна }}=\frac{\sum_{i=1}^{n} Q_{\mathrm{i} \phi} \times \mathrm{P}_{\mathrm{i} \phi}}{\sum_{i=1}^{n} Q_{\mathrm{i} \phi} \times \mathrm{P}_{\text {іп }}}$ & $\begin{array}{c}\mathrm{P}_{\text {iф }} \text { i } \mathrm{Q}_{\text {iф }}-\text { фактичні } \\
\text { ціни та кількість } \\
\text { товару і; } \\
\mathrm{P}_{\text {in }}-\text { планова ціна; } \\
\mathrm{n} \text { - кількість товарів }\end{array}$ \\
\hline \multicolumn{3}{|c|}{$\begin{array}{c}\text { Валютна ефективність експорту/імпорту } \\
\text { (показник валютної ефективності характеризує купівельну спроможність, } \\
\text { силу валюти, ії курс) }\end{array}$} \\
\hline $\begin{array}{c}\text { Валютна } \\
\text { ефективність } \\
\text { експорту } \\
\text { Якщо значення } \\
\text { показника перевищує } \\
\text { обернене значення } \\
\text { курсу національної } \\
\text { валюти - ЗЕД } \\
\text { є ефективною }\end{array}$ & $\mathrm{E}_{\text {в.е. }}=\frac{\sum_{i=1}^{m} \bigsqcup_{\text {в.е. }} \times Q_{\text {в.е. }}}{\sum_{i=1}^{n} \mathrm{~B}_{\mathrm{e}} \times Q_{\mathrm{e}}}$ & $\begin{array}{c}\text { Ц в.е. - валютна ціна } \\
\text { і-того товару на } \\
\text { експорт; } \\
\text { Qе - обсяг експорту } \\
\text { і-того товару; } \\
\text { Ве = витрати на } \\
\text { виробництво } \\
\text { та реалізацію } \\
\text { і-того товару; } \\
\text { m - кількість назв } \\
\text { експорту товарів }\end{array}$ \\
\hline
\end{tabular}


Продовження Таблиці 1

\begin{tabular}{|c|c|c|}
\hline 1 & 2 & 3 \\
\hline $\begin{array}{c}\text { Валютна } \\
\text { ефективність імпорту. } \\
\text { Якщо значення } \\
\text { показника перевищує } \\
\text { значення курсу } \\
\text { національної } \\
\text { валюти - ЗЕД } \\
\epsilon \text { ефективною }\end{array}$ & $\mathrm{E}_{\text {імпорт }}^{\text {вал }}=\frac{Ц_{\text {імпорт }}}{\mathrm{B}_{\text {імп }}^{\text {валютн }}}$ & $\begin{array}{c}\text { Цімп }- \text { вартість одиниці } \\
\text { імпортного товару; } \\
\text { В }_{\text {імп }} \text { вал }- \text { валютна ціна } \\
\text { одиниці товару }\end{array}$ \\
\hline $\begin{array}{c}\text { Валютна } \\
\text { ефективність } \\
\text { експорту }\end{array}$ & $\mathrm{E}_{\text {імпорт }}^{\text {вал }}=\frac{Ц_{\text {експ }}^{\text {вал }}}{\mathrm{B}_{\text {експ }}}$ & $\begin{array}{c}\text { Цексп }^{\text {вал }}-\text { валютна ціна } \\
\text { товару; } \\
\text { Вексп }- \text { витрати } \\
\text { на виробництво } \\
\text { та реалізацію } \\
\text { одиницю товару }\end{array}$ \\
\hline
\end{tabular}

Джерело: [2, с. 51]

Найбільш поширеною метою здійснення імпортних операцій підприємств є залучення іноземних товарів у власному виробництві. При визначенні ефективності імпорту товарів виробничого призначення особлива увага належить розрахунку ефективності імпортного устаткування та обладнання, яка може бути ви значена двома способами [3].

Згідно першого способу, визначається співвідношення економічного ефекту від придбання та використання альтернативного варіанту устаткування вітчизняного виробництва (ЕА) та економічного ефекту від придбання й використання імпортного обладнання (EI):

$$
\mathrm{E}_{\mathrm{e} \phi . \mathrm{i} .1}=\frac{\mathrm{EA}}{\mathrm{EI}},
$$

де $\mathrm{E}_{\text {еф.i.1 }}$ - показник порівняльної ефективності.

Якщо значення розрахованого показника більше 1, імпорт можна вважати ефективним. Економічний зміст розрахунку цього метода полягає у тому, що він показує, у скільки разів імпортна продукція (товар) є більш ефективною за альтернативну. Наголосимо, що показники економічного ефекту EI та EA за імпортним та альтернативним варіантами визначаються на основі витратних складових, які у сумі є відображенням ціни 
споживання товару: по-перше, це ціна придбання товару, тобто ціна контракту, митні платежі, транспортування, страховка, оплата послуг посередників тощо; по-друге, експлуатаційні видатки за весь період служби товару. Різниця між ЕА та EI це додатковий прибуток виробника при купівлі імпортної продукції замість альтернативної.

Другий спосіб полягає у визначенні ефективності імпорту виробничого обладнання, який, окрім витрат, враховує результативні показники і визначається як співвідношення обсягу продукції, що випускається протягом певного періоду на наявному устаткуванні (ОП), та ціною покупки імпортного обладнання. (Цпокуп.і.):

$$
\mathrm{E}_{\text {еф.i.2 }}=\frac{\text { оП }}{Ц_{\text {покуп.і. }}},
$$

де $\mathrm{E}_{\text {еф.i.2 }}$ - другий показник розрахунку ефективності імпорту. Цей показник відображає фондовіддачу i визначає вартість продукції, що випускається на даному устаткуванні, на 1 грн витрат на його придбання.

Існує думка, що оцінка ефективності експортної діяльності включає наступні напрямки (табл. 2).

Таблиця 2

\section{Оцінка ефективності експортної діяльності}

\begin{tabular}{|c|c|}
\hline Напрямок оцінювання & Локальні показники оцінки \\
\hline \multirow{4}{*}{$\begin{array}{l}\text { Ринкова } \\
\text { результативність } \\
\text { експорту }\end{array}$} & $\begin{array}{l}\text { Темпи зростання частки підприємства на зару- } \\
\text { біжному ринку }\end{array}$ \\
\hline & $\begin{array}{l}\text { Теми зростання частки експортної продукції в } \\
\text { загальних обсягах виробництва }\end{array}$ \\
\hline & $\begin{array}{l}\text { Темпи зростання обсягів реалізації продукції } \\
\text { підприємства }\end{array}$ \\
\hline & $\begin{array}{l}\text { Частка продукції, якість якої відповідає або } \\
\text { перевищує кращі зарубіжні аналоги, у загальних } \\
\text { обсягах виробництва }\end{array}$ \\
\hline \multirow{2}{*}{ Бюджетна ефективність } & $\begin{array}{l}\text { Зростання обсягів митних платежів у державний } \\
\text { бюджет країни, резидентом якої є підприємство- } \\
\text { експортер }\end{array}$ \\
\hline & $\begin{array}{l}\text { Темп зростання частки сплачених митних } \\
\text { платежів у загальному обсязі відрахувань до } \\
\text { державного бюджету }\end{array}$ \\
\hline
\end{tabular}




\begin{tabular}{|c|c|}
\hline 1 & 2 \\
\hline & $\begin{array}{l}\text { Співвідношення розміру фінансових потоків, } \\
\text { пов'язаних з обслуговуванням відповідно експор- } \\
\text { тних та імпортних операцій підприємства }\end{array}$ \\
\hline \multirow{4}{*}{$\begin{array}{l}\text { Виробничо- } \\
\text { технологічна } \\
\text { ефективність }\end{array}$} & $\begin{array}{l}\text { Зміни рівня завантаження основних виробничих } \\
\text { фондів (відносно показників альтернативного } \\
\text { варіанту побудови товарного асортименту під- } \\
\text { приємства, заснованого на відмові від експортних } \\
\text { поставок) }\end{array}$ \\
\hline & Темп змін ритмічності виробництва \\
\hline & $\begin{array}{llll}\begin{array}{l}\text { Темпи скорочення } \\
\text { продукції }\end{array} & \text { обсягів } & \text { запасів } & \text { готової } \\
\end{array}$ \\
\hline & Темпи змін фондовіддачі \\
\hline \multirow{3}{*}{$\begin{array}{c}\text { Ефективність } \\
\text { інноваційно- } \\
\text { інвестиційної діяльності }\end{array}$} & $\begin{array}{l}\text { Темпи зростання обсягів інвестицій у розвиток } \\
\text { матеріально-технологічної бази підприємства у } \\
\text { зв’язку з розширенням експортних поставок }\end{array}$ \\
\hline & $\begin{array}{l}\text { Зміни рівня зношеності основних фондів у зв'язку } \\
\text { із здійсненням відповідних капітальних вкладень }\end{array}$ \\
\hline & $\begin{array}{l}\text { Темпи змін частки інноваційної продукції, } \\
\text { призначеної для експортних поставок, у загальних } \\
\text { обсягах виробництва }\end{array}$ \\
\hline \multirow[b]{3}{*}{ Соціальна ефективність } & Темпи зростання продуктивності праці персоналу \\
\hline & Темпи змін рівня оплати праці персоналу \\
\hline & $\begin{array}{l}\text { Темпи змін частки чисельності персоналу } 3 \\
\text { найвищим рівнем кваліфікації } \\
\text { чисельності персоналу }\end{array}$ \\
\hline \multirow{5}{*}{$\begin{array}{c}\text { Фінансова } \\
\text { результативність }\end{array}$} & Зміна витрат на одиницю товарної продукції \\
\hline & $\begin{array}{l}\text { Співвідношення рівня цін реалізації продукції на } \\
\text { зовнішньому та національному ринках відповідно }\end{array}$ \\
\hline & Рентабельність виробництва експортної продукції \\
\hline & Рентабельність операційної діяльності \\
\hline & $\begin{array}{l}\text { Співвідношення обсягів короткострокової дебі- } \\
\text { торської та кредиторської заборгованостей }\end{array}$ \\
\hline \multirow{3}{*}{$\begin{array}{c}\text { Результативність } \\
\text { маркетингово-збутової } \\
\text { діяльності }\end{array}$} & Темпи зростання витрат на збут \\
\hline & $\begin{array}{l}\text { Темпи зростання оплати праці персоналу, задія- } \\
\text { ного в маркетингово-збутовій діяльності }\end{array}$ \\
\hline & $\begin{array}{l}\text { Частка витрат на маркетингове обслуговування } \\
\text { експортних поставок у загальних витратах на збут }\end{array}$ \\
\hline \multirow{2}{*}{$\begin{array}{c}\text { Результативність } \\
\text { скорочення експортних } \\
\text { ризиків }\end{array}$} & $\begin{array}{l}\text { Співвідношення розміру заявлених та фактично } \\
\text { сплачених митних платежів }\end{array}$ \\
\hline & $\begin{array}{l}\text { Співвідношення сплачених штрафів, пов'язаних } 3 \\
\text { експортними поставками, та отриманого від } \\
\text { експорту прибутку }\end{array}$ \\
\hline
\end{tabular}

Джерело: [4, с. 99] 
Отже, оцінка економічної ефективності експортно-імпортних операцій повинна базуватися на комплексному підході, метою якого $є$ оптимізація структури експорту та імпорту, оптимізація зовнішньоекономічних зв'язків та забезпечення беззбиткової діяльності підприємства.

\section{Література:}

1. Федоронько Н.І. Аналіз ефективності експортних та імпортних операцій. Світове господарство і міжнародні економічні відносини. 2016. Вип. 10. C. $120-122$.

2. Галунець Н.І., Васько Л.М. Методичні аспекти оцінки економічної ефективності зовнішньоторговельних операцій підприємств. Агросвіт. 2013. № 1 . С $50-53$.

3. Хоменко Т.Ю., Круш П.В. Методичні підходи до оцінки ефективності управління зовнішньоекономічною діяльністю. URL: https://ela.kpi.ua (дата звернення: 16.05.2021).

4. Бондарєва Т.I., Осадчук А.І. Оцінка ефективності експортної діяльності підприємства. Економіка та управління підприємствами маминобудівної галузі: проблеми теорії та практики. 2011. № 3(15). С. 91 - 103. 